\title{
Tabularity of individual turbidite beds controlled by flow efficiency and degree of confinement
}

\begin{tabular}{|r|l|}
\hline Journal: & Sedimentology \\
\hline Manuscript ID & SED-2017-OM-247.R1 \\
\hline Manuscript Type: & Original Manuscript \\
\hline Date Submitted by the Author: & n/a \\
\hline Complete List of Authors: & $\begin{array}{l}\text { liu, qun } \\
\text { Kneller, Ben; University of Aberdeen, Geology and Petroleum Geology } \\
\text { Fallgatter, Claus; university of aberdeen, Geology and Petroleum geology } \\
\text { Valdez, Victoria; University of Aberdeen, Geology and Petroleum Geology } \\
\text { Milana, Juan; Universidad Nacional de San Juan, Instituto de Geologia }\end{array}$ \\
\hline Keywords: & $\begin{array}{l}\text { submarine lobes, flow efficiency, degree of confinement, turbidite sheet } \\
\text { system, stacking patterns }\end{array}$ \\
\hline
\end{tabular}

\section{SCHOLARONE" \\ Manuscripts}




\title{
Tabularity of individual turbidite beds controlled by flow efficiency and degree of confinement
}

\author{
QUN LIU ${ }^{1}$, BEN KNELLER ${ }^{1 *}$, CLAUS FALLGATTER ${ }^{1}$, VICTORIA VALDEZ BUSO $^{1}$, JUAN PABLO \\ MILANA $^{2}$ \\ 1. School of Geosciences, University of Aberdeen, Aberdeen AB24 3UE, UK \\ (E-mail: b.kneller@abdn.ac.uk) \\ 2. Universidad Nacional de San Juan, Argentina
}

\begin{abstract}
Submarine lobes have various geometries and stacking patterns, whose differences are likely to be the result of variations in flow efficiency and degree of confinement. This study examines four contrasting units with differing flow efficiency and confinement, to evaluate their roles on bed geometries and stacking patterns. Three of these occur in the Late Palaeozoic Paganzo basin, NW Argentina: the Las Lajas system is developed in a $0.8 \mathrm{~km}$ wide palaeofjord; the Cerro Bola system (of which two different units were studied) was deposited in a larger sub-basin, of least $20 \mathrm{~km}$ width. The Paine $C$ system of the late Cretaceous Magallanes Basin in Chile is confined by an incision surface $3 \mathrm{~km}$ wide. 78 individual beds in the four units have been chosen to calculate flow efficiency and degree of confinement. Individual flow efficiency has been estimated semi-quantitatively by a bed's outcrop cross sectional area (as a proxy for flow volume) and percentage of mud in the beds (as a relative estimate for that in the flows). The degree of confinement experienced by the flows was assessed semi-quantitatively by dividing the flow efficiency by the maximum preserved basin dimension. It is found that: 1) Degree of confinement (efficiency divided by maximum preserved basin dimension) influences individual bed geometry, highly confined flows having a higher tabularity (smaller thinning rate); 2) In highly confined settings, individual beds stack vertically, whereas in unconfined systems, they stack compensationally; 3 ) Highly confined or high efficiency flows have higher tabularity (smaller thinning rate), which implies that truly sheet-like systems are only developed in highly confined and high efficiency systems. The generic model of architecture of submarine lobes and turbidite sheet systems, as a function of flow efficiency and degree of confinement, could be applied widely to sheet-like systems both at outcrop and in the subsurface.
\end{abstract}

Keywords Submarine lobes flow efficiency degree of confinement Turbidite sheet system stacking patterns

\section{INTRODUCTION}

The term submarine lobe (or splay) refers to a sediment body developed at the terminus of or lateral to a submarine channel, typically represented as having a roughly lobate, ovoid or fan-like shape 
(suprafan lobe and lower fan of Normark, 1970, 1978; Mutti and Normark, 1987; Pirmez et al., 2000; Posamentier and Kolla, 2003). Lobes are generally considered to have broadly sheet-like internal architectures, at least as far as bed geometries can be discerned in outcrop, and the terms 'sheet system' and 'lobe' are often used more or less interchangeably.

In this paper, the term 'submarine lobe' has been used to refer to systems in which the internal architecture is largely if not entirely controlled by the dynamics of the flows that build the lobe rather than any surrounding topography. We use the term 'turbidite sheet system' to refer to any turbidite depositional system where the individual beds are more or less tabular or are lenticular with very high aspect ratios (typically well in excess of $10^{2}$ ). Neither term implies that the system consists wholly of turbidites, and either might include a debrite or hybrid component.

The nature of such systems has sometimes been interpreted in terms of 'flow efficiency', a qualitative concept proposed by Mutti (1979) to describe the ability of a flow to deliver sand in a basinward direction, i.e. the run-out distance. Flow efficiency is controlled by flow volume and percentage of fine-grained material in suspension (Mutti, 1992). Amy et al. (2000), Samuel et al. (2003) and Al Ja'aidi et al. (2004) proposed that flow concentration also played a role.

The form of sheets or lobes may be controlled largely by the degree to which they are contained or confined by the topography. Confinement refers to the degree to which sediment gravity flows are influenced by the surrounding basin relief (Mutti \& Ricci Lucchi, 1978; Thornburg et at., 1990; Weaver et al., 1992; Kneller, 1995; Smith, 2004; Lomas and Joseph, 2004). Confined settings can occur wherever there is negative relief on the sea floor. On large scales, they may occur in virtually any type of structurally-controlled basin, such as fore-arc settings (Vinnels et al., 2010), foreland basins (Sinclair, 1994; Haughton, 2000; Amy et al., 2007; Felletti and Bersezio, 2010), rift basins (Ravnås and Steel, 1997), intraslope salt-withdrawal basins (Winker, 1996; Prather, 1998; Beaubouef et al., 2003), and those affected by salt or shale diapirism (Van Rensbergen et al., 1999). On small scales, they can occur in the relief on the top of mass-transport deposits (Armitage et al., 2009; Kneller et al., 2016). Whether flows are confined depends upon on their run-out distance relative to the basin size.

Various studies have suggested that apparently sheet-like turbidite systems with low flow efficiency in unconfined settings are more likely to show wedge geometry and compensational stacking architecture, i.e. individual beds are discontinuous and pinch out rather quickly in response to thickening of the underlying bed (e.g. Dudley et al., 2000; Deptuck et al., 2008; Jegou, et al., 2008; Prélat, et al., 2010; Marini et al., 2015), whereas those systems developed in high efficiency, highly confined settings are more likely to show tabular geometries (continuous beds with a smaller rate of lateral thinning), typically showing more or less vertical stacking, without systematic offset (Haughton, 1994; Remacha and Fernandez, 2003, 2005; Talling et al., 2007). However, the relationship between flow efficiency and confinement on the one hand and stacking patterns and individual bed tabularity on the other have not yet been established.

This paper, for the first time, attempts to quantify flow efficiency and degree of confinement, and their effects on architectural styles. We present detailed field data from four contrasting systems in order to demonstrate the effects of these controls on spatial changes and likely lateral continuity of 
individual turbidite beds. Finally, we suggest a generic model for submarine lobe or sheet system architecture based on flow efficiency and degree of confinement in the system.

\section{GEOLOGICAL CONTEXT}

\section{Geographic setting of the three field areas}

The datasets are taken from three field areas (Fig.1A). Two of the study areas (Cerro Bola and Las Lajas), are developed in the Carboniferous Paganzo Basin in northwest Argentina, in the timeequivalent Guandacol and Jejenes Formations (Bashkirian; Valdez Buso et al., 2017). The tectonic setting of the Paganzo Basin has been described as a retro-arc foreland basin (Ramos, 1989), a strike-slip basin (Fernández Seveso \& Tankard, 1995), or half-graben (Milana et al., 2010). The basin was connected by narrow seaways to the open ocean to the west, with a continental ice sheet to the east (Fig. 1B). During mid-Carboniferous times, the basin experienced several glacial events, followed by melting and consequent flooding of the continental landmass (Lopez-Gamundi et al, 1992).

The Cerro Bola area (Figs.1, 2, Table 1), where two of the studied systems occur, is in the northern part of the basin (Fernández Seveso and Tankard, 1995; Limarino et al., 2002). The sub-basin width of at least $20 \mathrm{~km}$ is constrained by onlap of the more distal parts of the section onto basement in the northwest, and the width of the exposed section approximately parallel to the palaeocurrents. In contrast, Las Lajas outcrops, to the SSW (Figs 1, 3, Table 1), occur within a c.1 km wide palaeofjord, incised into the Ordovician San Juan Formation limestones. The onlap onto the fjord walls is well exposed on both sides of the fjord (Dykstra et al., 2006).

- The Silla syncline, is within the Magallanes Basin, located in Patagonia, southern Chile (Fig. 1C), in Torres del Paine National Park. It is regarded as part of a N-S retro-arc foreland basin (Biddle et al., 1986; Wilson 1983. 1991). The Silla syncline includes deposits of the Cerro Toro Formation (Campanian), which records the southward filling of the foreland basin (Fig. 1C) (Crane and Lowe, 2008), and which we interpret as lower to middle slope deposition. The Cerro Toro Formation is exposed as a series of generally north to south striking ridges in the fold and thrust belt east of the Andean Cordillera, and this study focuses on the exposures around the Silla Syncline (Fig. 1C).

The three studied outcrops therefore represent beds deposited in basins ranging in widths of over an order of magnitude $(0.8 \mathrm{~km}$ to $20 \mathrm{~km})$ and within sand percentage sequences ranging by a factor of $\underline{2(0.40-0.99)}$.

\section{Cerro bola study area}

Cerro Bola exposes an inlier of upper Palaeozoic section in a large, doubly-plunging, north-south oriented, hanging wall anticline to a thrust that dips east at about 24 (Fig. 2A) (Milana et al., 2010; Dykstra et al., 2011) of Neogene to Recent age (Zapata and Allmendinger, 1996; Jordan et al., 2001).

The succession exposed in the Cerro Bola anticline records alternations between fluvio-deltaic sediments, turbidite intervals and aquatills (Dykstra et al., 2011) (Fig. 2B). The overall shallowing- 
upward succession ranges from Carboniferous to Permian over a total stratigraphic thickness exceeding 1 km (Fig. 2B, Milana et al., 2010; Dykstra et al., 2011; Fallgatter et al., 2017). Correlative strata occur at Sierra de Maz, approximately $10 \mathrm{~km}$ to the NW, restoring to perhaps $15 \mathrm{~km}$ after removal of thrust displacement (Milana et al., 2010; Valdez Buso et al., 2015), where Mississippian/Pennsylvanian rocks are seen to onlap metamorphic Precambrian basement, uplifted along the currently active Valle Fertil fault.

Within the Bashkirian (early Pennsylvanian) part of the Cerro Bola succession is a unit of turbidites (Milana et al., 2010; Dykstra et al., 2011; Fallgatter et al. 2015; 2017). These turbidites have been divided into five stages (named TS1 to 5; Fig. 2; Fallgatter et al., 2015, 2017), of which two, TS2 and TS4 (Fig. 2B) (Fallgatter et al., 2017), have been chosen for detailed bed-to-bed correlation. The general palaeocurrent direction is towards the northwest, which means the existing outcrop is oblique to the depositional dip direction. Both TS2 and TS4 are about $25 \mathrm{~m}$ in total thickness. TS2 is a very sandy system, with $95 \%$ sand, whereas TS4 has $75 \%$ sand (Table 1).

\section{Las Lajas study area}

Quebrada de las Lajas, near San Juan city, western Argentina, preserves an exactly co-eval Bashkirian (Valdez Buso et al., 2017) glacial to postglacial succession that was deposited in an overdeepened palaeofjord (Dykstra et al., 2006) (Fig. 3A). The sedimentary succession has been divided by Dykstra et al. (2006) into four evolutionary stages: I, an ice-contact delta and proglacial lake; II, a relatively quiet, deep-water marine environment punctuated by turbidity currents; III, an aggradational, confined, relatively deep-water turbidite sheet sand system; and IV, the subaqueous portion of a progradational, coarsening and shoaling-upward coarse-grained delta (Fig. 3B). The entire sedimentary succession comprises approximately 350m exposed thickness (Fig. 3C), with the walls of the palaeofjord being visible at outcrop.

The studied interval is part of the stage III turbidites and is around $40 \mathrm{~m}$ thick, with about $40 \%$ sand. The outcrop is very well exposed, and the individual beds we have chosen for the correlation are virtually $100 \%$ exposed observed along the line of correlation. Three dimensionality of the outcrop confirms the correlations.

\section{Silla syncline study area}

The Cerro Toro Formation in the Silla syncline (Fig.4A) is at least 1100m thick and includes three major conglomerate and sandstone units (the Pehoe, Paine and Nordenskjold members; Crane and Lowe, 2008) within a background of thin-bedded sandstone and dark grey mudstone (Fig. 4B, 4C). The Paine member is regarded as part of a confined slope system (Beaubouef, 2004), with an alternation of channel and lobe deposition (Crane and Lowe, 2008; Bernhardt et al., 2011). The Paine Member has been divided into three sub-members, Paine A, B and C. Paine $C$ is itself sub-divided into three phases; phases 1 and 2 represent the channel-fill, while phase 3 represents the succeeding sandy lobe (Bernhardt et al., 2011) that passively infills the residual channel relief. In this paper, we use the term Paine $C$ to refer only to the phase 3 sandy lobe infill. This consists of an $80 \mathrm{~m}$ section of 
turbidites, confined by the erosion surface that bounds the underlying channel fill, with a width of $3 \mathrm{~km}$. It is a very sandy system, with up to $99 \%$ sand. Palaeocurrents are towards to southeast, oblique to the outcrop we have correlated.

\section{METHODS}

Between the four units, eighteen sections (540m in total) were logged at a scale of 1:20 to capture lithology, grain size, sedimentary structures, silt and mud percentage and bed boundaries. The correlation framework is constrained by walking bed boundaries between sections where possible, augmented with high-resolution ground-based and UAV panoramic photomosaics. 78 individual beds are chosen and correlated in the four studied units, the smallest maximum whole bed thickness of which are: Paine C $58 \mathrm{~cm}$, Las Lajas $56 \mathrm{~cm}$, TS2 $60 \mathrm{~cm}$, TS4 $90 \mathrm{~cm}$. The cross sectional area of individual beds at outcrop, $A$, has been used as a semi-quantitative proxy for the relative volumes of the parent flows (Talling et al., 2007; Malgesini et al., 2015). It has been calculated using $\mathrm{A}=\frac{1}{2} \sum_{i=1}^{n}\left(B_{i}+B_{i+1}\right) D_{i}$, where $\mathrm{n}$ is the number of logs that provide constraints in this study, $\mathrm{B}_{\mathrm{n}}$ is bed thickness at $\log n$, and $D_{i}$ is the distance between successive logs in a down-current direction. Percentage of silt and mud in individual beds, $P$, is estimated by the thickness of silt and mud in the individual beds divided by the whole bed thickness, expressed as a percentage.

$P=M_{1}+M_{2}+\ldots M_{n} / B_{1}+B_{2}+\ldots B_{n} M_{n}$ is the mud and silt cap of individual bed, $B_{n}$ represent the thickness of the whole bed. Although an imperfect reflection of the proportion of fine-grained material in the parent flow, it is the best proxy available for the relative proportions. Individual bed average thinning rate $(\% / \mathrm{km})$ in the depositional dip direction has been calculated by the bed thickness variation between the adjacent logs: $\mathrm{T}=\sum_{i=1}^{n}\left(B_{i+1}-B_{i}\right) / D_{i} \mathrm{n}$, where $\mathrm{B}_{\mathrm{i}+1}$ and $\mathrm{B}_{\mathrm{i}}$ are the thickness in successive logs in a down-current direction log; $D_{\mathrm{i}}$-Distance between the two logs, $n$-the number of logs taken in this study. We have not attempted to differentiate thin mud turbidites from the mud caps of thicker beds as this generally cannot be reliably done. Where it is possible, it is seen that the turbidite mud makes up all or almost all of the mud thickness. We thus take the top of the mud cap as the base of first differentiable succeeding event. This is bound to involve some error, but given the substantial thickness of the beds in question, we argue that the error is small and systematic. In addition, although mud may have been eroded from the top of some of the beds, especially where sandstone beds are amalgamated, the error involved will undoubtedly be less than the observed differences between systems.

\section{RESULTS}

\section{Individual bed characteristics of TS2 system}

TS2 is about $25 \mathrm{~m}$ thick (Fig.5A). The correlation panel goes from NNE to SSW (Fig.5B), which is oblique to the main palaeocurrent direction (N-NW) (Fig.5B). The well exposed outcrop (Fig. 5C, 5D) 
and numerous logs in the TS2 interval allow us to capture the pinch-out of individual beds (bed 1-bed 21) along the outcrop (Fig. 5A). Individual beds wedge out along the outcrop, losing both thickness and sand percentage. Bed packages up to $8 \mathrm{~m}$ thick (Fig. 5C) with a mean sand thickness of $40 \mathrm{~cm}$ and overall sand percentage of $80 \%$, change laterally into thin-bedded turbidites with a mean sand thickness of $5 \mathrm{~cm}$, overall sand percentage $20 \%$ and overall thickness of $5 \mathrm{~m}$, over distances of about 5 km oblique to palaeocurrent (Fig. 5A). The individual bed generally consists of a minor mud cap, constituting $2 \%-5 \%$ of the whole bed thickness. The calculated average individual bed thinning rate in TS2 is $40 \% / k m$. In TS2, some individual beds (beds 1 to 14 for instance) exhibit maximum thickness in the north, whereas some individual beds (e.g. beds 14 to 21) have their maximum thickness in the south, indicating changes in depocentre.

\section{Individual bed characteristics of TS4 system}

TS4 turbidite sandstones are fully exposed in a 7.6km oblique dip direction (Fig.6A) and they onlap basin margin basement. This restores after removal of thrust displacement to (Milana et al., 2010) to at least $12 \mathrm{~km}$ from Cerro Bola in a depositional dip direction, providing a total correlation length of approximately $20 \mathrm{~km}$. The palaeocurrents are mainly towards NW (Fig.6B).

Individual beds exhibit tabular geometry (Fig.6) and all the larger beds (except bed 8) extend the entire length of the oblique down-current section. This contrasts with TS2, where all the individual beds pinch out within the $7.6 \mathrm{~km}$ correlation panel at Cerro Bola. Also, the fact that most of the individual beds (bed 1-3, 7, 9-11, 13-14) appear near the onlap implies a degree of confinement, unlike TS2, in which all the beds have pinched out before reaching the onlap.

Individual beds in TS4 always include significant mud caps, generally constituting around $30 \%$ of

the total bed thickness. There is no systematic vertical trend in the maximum thickness of individual beds. In general the individual beds aggrade vertically to build the whole TS4 unit.

\section{Individual bed characteristics of Las Lajas system}

The measured turbidite interval in Las Lajas is around 40m thick (Fig.7A), and four logs have been measured in a depositional dip direction. Individual beds typically have a thick mud cap (Fig.7), indicating the high mud percentage within the flow as well as the highly confined environment which facilitates the ponding of mud. It could be seen that the individual beds (Bed 1-Bed 18) are tabular at a scale of 500m (Fig. 7B), and individual beds are easily traced and correlated in the field (Fig. 7C and Fig. 7D).

\section{Individual bed characteristics of Paine C system}

The Paine $C$ turbidite sandstone interval is $32 \mathrm{~m}$ thick and is stratigraphically situated between underlying channel-fill conglomerates and a distinctive debrite above, which serve as good stratigraphic markers (Fig. 8A). The deposits are very sandy and highly amalgamated (Fig. 8B), pinching out (Fig. 8C), scouring (Fig. 8D) and amalgamation of individual beds (Fig. 8E) are commonly seen in the outcrop. Amalgamation surfaces (sand-sand bed boundaries) are usually 
marked by granule-grade intervals (Fig. 8D). In general, the individual beds are not sheet-like even at a horizontal scale of $50 \mathrm{~m}$ (Fig. 8F). Twenty-five individual beds (beds that are thicker than $60 \mathrm{~cm}$ ) have been chosen for detailed correlation (Fig.8A).

\section{Individual bed outcrop cross-sectional area and percentage of silt and mud}

The beds in Paine $\mathrm{C}$ have the lowest percentage of silt and mud of the four systems studied, with a narrow range from $0.2 \%-0.5 \%$ (Table 2) (Fig. 9), TS2 ranging from $2 \%-5 \%$ silt and mud, TS4 ranging from $20 \%$ to $36 \%$, while the silt and mud percentage is significantly higher in beds of Las Lajas, with a range from $34 \%-76 \%$. In order of outcrop cross sectional area, beds in TS4 have the largest outcrop cross sectional area (ranging from 3680 to $30380 \mathrm{~m}^{2}$ ), averaging $1.1 \times 10^{4} \mathrm{~m}^{2}$; Las Lajas (from 1200 to $11600 \mathrm{~m}^{2}$ ), average $4.1 \times 10^{3} \mathrm{~m}^{2}$; TS2 (from 960 to $4890 \mathrm{~m}^{2}$ ), average $2.5 \times 10^{3} \mathrm{~m}^{2}$; and lastly Paine $\mathrm{C}$, ranging from 290 to $1340 \mathrm{~m}^{2}$, average $6 \times 10^{2} \mathrm{~m}^{2}$ (Table 2).

The four systems can thus be well differentiated by mean outcrop cross sectional area of the individual beds within them, and percentage of silt and mud (Fig. 9). The cross sectional area of a bed at outcrop can be taken as a crude proxy for flow volume, on the assumption that bed thickness reflects flow size, and that the plan-view shape of the beds is not grossly anisotropic. The inevitable errors within these estimates are far outweighed by the differences between the diferent systems. Despite the caveats above, the percentage of silt and mud within a bed is the best available proxy for proportion of fines in the parent flow, although there may be a systematic bias due to ponding of mud in more confined settings (Lamb et al., 2006; Marini at al., 2016).

\section{The semi-quantitative representation of flow efficiency and degree of confinement}

Flow efficiency is determined by both flow volume and percentage of silt and mud in each flow. We have attempted to give a semi-quantitative evaluation of flow efficiency, using the simple product of bed cross-sectional area (as an approximate measure of relative flow volume) and percentage of mud and silt within the beds (as a rough measure of the relative proportions within the flows). We thus use the simple expression E=AP (where $E$ is flow efficiency, $A$ is outcrop cross-sectional area, and $P$ is percentage of silt and mud) to parameterise flow efficiency in these four systems. This assumes that flow volume and percentage of silt and mud have roughly equal effects on flow efficiency. This assumption is borne out by the experimental results of Al Ja'aidi (2000), who showed that the increase in delivery of sediment to the basin floor was more or less equally influenced by changes in flow volume and percentage of silt and mud.

The degree of confinement in these systems is the degree to which the flows interact with the bounding topography. Since this will depend on the ability of the flows to reach the margins, it will be governed by flow efficiency, but it will also depend upon the basin size. Flows that interact with the basin margins (and may be deflected or reflected) tend to deposit beds whose geometries are controlled by those interactions (typically tabular), whereas those which are unconfined produce deposits with architectures and stacking patterns that are more likely to be self-organised. We have 
evaluated confinement semi-quantitatively using the expression: $D=E / M$, where $D$ is degree of confinement, $E$ is flow efficiency, and $M$ is maximum preserved basin dimension. As for flow volume, this also assumes that the basins are not grossly anisotropic. Where these systems are in markedly elongate basins (long and laterally-confined) it raises the possibility that the stratigraphic organisation may be a function of orientation, with architectures in a depositional dip direction being controlled by basin length, while the organisation in a cross-stream direction is controlled by basin width.

Using the expression given above, we find TS4 has the highest flow efficiency $\left(2.8 \times 10^{3}\right)$ and Paine C the lowest (1.8), and Las Lajas the highest degree of confinement (2700), and Paine $C$ the lowest (0.6) (Table 3). Thus it can be seen that the degree of confinement is not defined by absolute basin size, but by its size relative to the efficiency of the turbidite system.

\section{Individual bed tabularity}

Thinning rates $(\% / \mathrm{km})$, which means the percentage of bed thickness change over distances, could be best used to describe the geometry and tabularity of individual beds. Individual beds thickness decay differently in the four studied systems, i.e. exhibit different thinning rates. Taking TS2 and TS4 as examples (Fig.10); individual beds in TS2 follow an exponential decay in thickness, while individual beds in TS4 obey a power law decay (Fig.10), in which case, beds in TS2 generally pinch out within $\underline{4 \mathrm{~km}}$ and beds in TS4 only show decay in the first $3 \mathrm{~km}$ and maintain nearly the same thickness all the up to the basin margin.

Also, the four studied systems show large differences in average thinning rates (Fig.10-11 A-C; Table 3), ranging from 65\%/km (Paine C), to 3\%/km (Las Lajas). In other words, individual beds in Las Lajas and TS4 have much higher tabularity than TS2 and Paine C. Also, thinning rates in Paine C

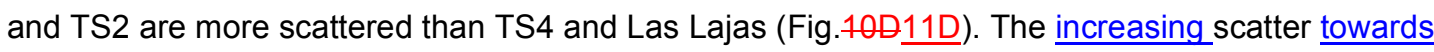
the left in Fig. $11 \mathrm{~A}, \mathrm{~B}$ and $\mathrm{C}$ in Paine $\mathrm{C}$ and TS2 areis very likely to be the result of non-linearity of individual beds thinning rate, which becomes harder to evaluate which we cannot accessas bed correlation lengths decrease.

Outcrop cross sectional area and flow efficiency show negative relationships $\left(R^{2}=0.72,0.73\right)$ with individual bed thinning rates $(\% / \mathrm{km})$ in TS2, Paine C and TS4, but not in Las Lajas (Fig 10A11A, 10BB $)$. Degree of confinement shows negative relationship the best fit $\left(R^{2}=0.84\right)$ with thinning rates $(\% / \mathrm{km})$ in four systems. Las Lajas is an outlier in these relationships since the cross-sectional area measurements are limited by the width of the fjord, whereas these beds probably extend for long distances in a depositional dip direction; they have thus been excluded from the best-fit calculations.

\section{DISCUSSION}

\section{Controls on individual bed tabularity}


1

2

3

4

5

6

7

8

10

Scatter plots of degree of confinement and flow efficiency vs. thinning rate (Fig. 10B $\underline{11 B}, 10 \mathrm{C} \underline{\mathrm{C}}$ ) show that flow efficiency and degree of confinement play a key role in determining the individual bed depositional thickness change and thus the correlation length of individual beds. As mentioned above, flow efficiency in each system can be represented by the-flow size (outcrop cross sectional area in ancient systems) and percentage of silt and mud in each system (Fig. 11A $12 \mathrm{~A})$. Turbidite systems in general are quite diverse, with individual flows differing in percentage of silt and mud and in flow volume (Cossey and Kleverlaan, K., 1995; O'Connell et al., 1995; Gorsline, 1996; Badalini et al., 2000; Gorsline et al., 2000; Haughton, 2000; Johnson et al., 2001; Wynn et al., 2002; Lien et al., 2003; Hodgson and Haughton, 2004; Amy and Talling, 2006; Gervais et al., 2006; Covault et al., 2007; Talling et al., 2007; Deptuck et al., 2008; Jegou et al., 2008; Ducassou et al., 2009; Prélat et al., 2009; Prélat et al., 2010; Etienne et al., 2012; Palacios, 2012; Prather et al., 2012; Picot et al., 2016; Dennielou et al., 2017;) (Fig. 12A).

We were able to differentiate the four systems based on the average flow efficiency and degree of confinement (Fig. 12B, Table 3): TS4 being a high efficiency, moderate confined system; Las Lajas is a moderately efficient and highly confined system; TS2 is a low efficiency, loosely confined sytem; and Paine $\mathrm{C}$ is a low efficiency unconfined system. The average thinning rate ofin each these systems decreases from the low efficiency unconfined systems like Paine $C(65 \% / \mathrm{km})$ to high efficiency highly confined systems like Marnoso Arenacea (1\%/km) (Amy and Talling et al., 2006; Talling et al., 2007) and Las Lajas (3\%/km) (Fig. 12B). Flow efficiency is higher in TS4 than in PeïraCava, but Peïra-Cava has lessa smaller average thinning rate (10\%/km) (Amy et al., 2000a) than in TS4 (15\%/km) due to higher degree of confinement (Fig. 12B). Flows in Peïra-Cava and Ross sandy units (Pyles., 2007) haveare inferred to have nearly the same flow efficiency, but in Peïra-Cava the beds hashows a much essmallser average thinning rate than in Ross $(35 \% / \mathrm{km})$ due to higher degree of confinement. Flows in TS4 and Ross sandy units are-experienceding thea similar degree of confinement, but flowsbeds in TS4 have lesssmaller average thinning rates than Ross sandy units, due to a higher flow efficiency (Fig. 12B). TS2 and Annot (Etienne et al., 2012) have same-similar thinning rates $(40 \% / \mathrm{km})$, with TS2 being higher in flow efficiency but less in-confinedment than Annot. Note that in all these cases the term unconfined refers to individual flows and their resulting beds with respect to the bounding surfaces, and not to the geometry of the system as a whole.

The variability of individual bed thickness change rate documented in this study points out the importance of assessing flow efficiency and degree of confinement in an unknown system. Flow efficiency could be semi-quantitatively evaluated by bed thickness, correlation length and sand percentage. Basin size could be reconstructed from seismic data. By knowing flow efficiency and basin size of the system, a semi-quantitative estimate of degree of confinement could be obtained, which aids estimation of the thinning rate of individual beds in the system (Fig.11C; Fig.12B)

\section{Turbidite sheet systems architecture and its controls}

A simplified cartoon based on the real data has been drawn to represent the architecture of each of the four systems (Fig. 13). In Paine C, a low efficiency and unconfined system, the sandstones have 
large rates of thickness change (Fig. 11). Even though the system is bounded by an erosion surface, many of the flows are so inefficient that they did not reach the margin and are thus loosely- to unconfined. In TS2, a low efficiency moderately confined system, individual beds also have large rates of thickness change (Fig. 11), and individual beds pinch out into sand-poor thin-bedded turbidites before reaching the basin margin. Bed packages stack compensationally, as do individual beds in what we interpret as the axial parts of each package. In Las Lajas, a moderate efficiency highly confined system, individual beds have little thickness change_(Fig. 11) and very high silt and mud percentage, which may in part be due to ponding. In TS4, a high efficiency highly confined system, individual beds also have a tabular character, extending all the way across the exposed part of the basin.

- We recognise that in_confined systems (e.g. high flow efficiency systems such as TS4 and Las Lajas; Fig. 1213; Table 4), individual beds may extend across the entire basin to create basin-wide turbidite beds with low thinning rates (e.g. Sumner et al., 2012; Wynn et al., 2012).The turbidite beds in these systems aggrade vertically. In unconfined systems (e.g. low efficiency flows in small basins) the beds have relatively higher rates of thickness change. In systems such as TS2 and Paine $C$, the individual beds have large rates of thickness change over short distances, so they are more likely to stack in a compensational way (e.g. Rozman, 2000).

It may be deduced that systematic vertically thickening and thinning upward trends are a result of autocyclicity in unconfined (often low efficiency) lobe systems, but are more likely due to allocyclicity in confined (often high efficiency) systems.

\section{CONCLUSIONS}

Our study demonstrates that the overall character of sheet-like turbidite systems is determined by a combination of factors: (A) flow efficiency, which in turn is the product of the percentage of fines within the flow, and the flow size; and (B) the degree of confinement, which depends on the efficiency of the flows with respect to the size of the basin, the resulting architecture being dependent on flow interaction with the basin margins. We have for the first time attempted to quantify these parameters, using proxies that are crude and relative, but are the best available in ancient deposits. In any case, we assert that the errors in these measures are likely to be smaller than the differences between distinct types of system, though they are unlikely to be an accurate reflection of small differences between similar systems.

Based on these estimates we note a simple correlation between these parameters and the rate of thickness decay in individual beds, which is a measure of their tabularity. Outliers from these correlations occur where the basin is small and the estimates of flow size are subject to large uncertainties (for example due to limited outcrop length relative to the basin width or length). 


\section{REFERENCES}

Al Ja'Aidi, O.S. (2000) The influence of topography and flow efficiency on the deposition of turbidites. Unpublished PhD thesis. University of Leeds, UK, 162p.

Al Ja'Aidi, O. S., McCaffrey, W. D., \& Kneller, B. C. (2004) Factors influencing the deposit geometry of experimental turbidity currents: implications for sand-body architecture in confined basins. Geol. Soc. London Spec. Publ., 222, 45-58.

Amy, L. A., Kneller, B., \& McCaffrey, W. D. (2000) Evaluating the links between turbidite characteristics and gross system architecture: upscaling insights from the turbidite sheet system of Peira Cava, SE France. Deep-Water Reservoirs of the World: Houston, SEPM, Gulf Coast Section, 1-15.

Amy, L. A., and Talling, P. J. (2006) Anatomy of turbidites and linked debrites based on long distance $(120 \times 30 \mathrm{~km})$ bed correlation, Marnoso Arenacea Formation, Northern Apennines, Italy. Sedimentology, 53, 161-212.

Amy, L. A., Kneller, B. C., \& McCaffrey, W. D. (2007) Facies architecture of the Gres de Peira Cava, SE France: landward stacking patterns in ponded turbiditic basins. J. Geol. Soc., 164, 143-162.

Armitage, D.A., Romans, B.W., Covault, J.A. and Graham, S.A. (2009) The influence of mass-transport-deposit surface topography on the evolution of turbidite architecture: The Sierra Contreras, Tres Pasos Formation (Cretaceous), southern Chile. J. Sed. Res., 79, pp.287-301.

Badalini, G., Kneller, B. and Winker, C.D. (2000) December. Architecture and processes in the late Pleistocene BrazosTrinity turbidite system, Gulf of Mexico continental slope. In Deep-Water Reservoirs of the World: SEPM, Gulf Coast Section, 20th Annual Research Conference. pp. 16-34.

Beaubouef, R. T. (2004) Deep-water leveed-channel complexes of the Cerro Toro Formation, Upper Cretaceous, southern Chile. AAPG Bull., 88, 1471-1500.

Beaubouef, R. T., Abreu, V., \& Van Wagoner, J. C. (2003) Basin 4 of the Brazos-Trinity slope system, western Gulf of Mexico: The terminal portion of a late Pleistocene lowstand systems tract. In Shelf margin deltas and linked down slope petroleum systems: Global significance and future exploration potential: Proceedings of the 23rd Annual Research Conference, Gulf Coast Section SEPM Foundation. pp. 45-66.

Bernhardt, A., Jobe, Z. R., \& Lowe, D. R. (2011) Stratigraphic evolution of a submarine channel-lobe complex system in a narrow fairway within the Magallanes foreland basin, Cerro Toro Formation, southern Chile. Mar. Petrol. Geol., 28, 785-806.

Biddle, K.T., Uliana, M.A., Mitchum, R.M., Jr., Fitzgerald,M.G., and Wright, R.C. (1986) The stratigraphic and structural evolution of the central and eastern Magallanes Basin, southern South America, in Allen,P.A., and Homewood, P., eds., Foreland basins: Int. Assoc. Sedimentol. Spec. Publ., 8, 41-61.

Buatois, L. A., \& Mángano, M. G. (1995) The palaeoenvironmental and palaeoecological significance of the lacustrine Mermia ichnofacies: an archetypical subaqueous nonmarine trace fossil assemblage. Ichnos: An International Journal of Plant \& Animal, 4, 151-161.

Cossey, S.P.J. and Kleverlaan, K. (1995) Heterogeneity within a sand-rich submarine fan, Tabernas Basin, Spain. In Atlas of Deep Water Environments. pp. 157-161.

Covault, J.A., Normark, W.R., Romans, B.W. and Graham, S.A. (2007) Highstand fans in the California borderland: The overlooked deep-water depositional systems. Geology, 35,783-786.

Crane, W. H., \& Lowe, D. R. (2008) Architecture and evolution of the Paine channel complex, Cerro Toro formation (Upper Cretaceous), Silla syncline, Magallanes basin, Chile. Sedimentology, 55, 979-1009. 
Deptuck, M. E., Piper, D. J., Savoye, B., \& Gervais, A. (2008) Dimensions and architecture of late Pleistocene submarine lobes off the northern margin of East Corsica. Sedimentology, 55, 869-898.

Dennielou, B., Droz, L., Babonneau, N., Jacq, C., Bonnel, C., Picot, M., Le Saout, M., Saout, Y., Bez, M., Savoye, B. and Olu, K. (2017) Morphology, structure, composition and build-up processes of the active channel-mouth lobe complex of the Congo deep-sea fan with inputs from remotely operated underwater vehicle (ROV) multibeam and video surveys. Deep-Sea Res. Part II: Topical Studies in Oceanography.

Ducassou, E., Migeon, S., Mulder, T., Murat, A., Capotondi, L., Bernasconi, S.M. and Mascle, J. (2009) Evolution of the Nile deep - sea turbidite system during the Late Quaternary: influence of climate change on fan sedimentation. Sedimentology, 56, 2061-2090.

Dudley, P. R., Rehmer, D. E., \& Bouma, A. H. (2000) Reservoir-scale characteristics of fine-grained sheet sandstones, Tanqua Karoo Subbasin, South Africa. In Deep-Water Reservoirs of the World: SEPM, Gulf Coast Section, 20th Annual Research Conference, Houston, Texas (pp. 318-341).

Dykstra, M., Kneller, B., \& Milana, J. P. (2006) Deglacial and postglacial sedimentary architecture in a deeply incised palaeovalley-palaeofjord-The Pennsylvanian (late Carboniferous) Jejenes Formation, San Juan, Argentina. Geol. Soc. Am. Bull, 118, 913-937.

Dykstra M., Garyfalou, K., Kertznus, V., Kneller, B., Milana, J-P., Molinaro, M., Szuman M. and Thompson, P. (2011) Mass-transport deposits: Combining outcrop studies and seismic forward modeling to understand lithofacies distributions, deformation and their seismic expression. In R.C. Shipp, P. Weimer y H. W. Posamentier (Eds.), Mass-transport Deposits in Deepwater Settings. SEPM Spec, 96,293-310.

Etienne, S., Mulder, T., Bez, M., Desaubliaux, G., Kwasniewski, A., Parize, O., ... \& Salles, T. (2012). Multiple scale characterization of sand-rich distal lobe deposit variability: examples from the Annot Sandstones Formation, Eocene-Oligocene, SE France. Sed. Geol., 273, 1-18.

Fallgatter, C. (2015) Confined to unconfined deep-water systems of the Paraná (Brazil) and Paganzo (Argentina) basins. PhD thesis. Universidade do Vale do Rio dos Sinos. 208.

Fallgatter, C., Kneller, B., Paim, P. S. G. and Milana, J. P. (2017) Transformation, partitioning and flow-deposit interactions during the run-out of megaflows. Sedimentology, 64: 359-387.

Felletti, F., \& Bersezio, R. (2010) Quantification of the degree of confinement of a turbidite-filled basin: a statistical approach based on bed thickness distribution. Mar. Petrol. Geol., 27, 515-532.

Fernández Seveso, F. and Tankard. A. (1995) Tectonics and Stratigraphy of the late Palaeozoic Paganzo Basin of western Argentina and its regional implications, In: Tankard, A., Suarez, S., and Welsink, H.J., eds., Petroleum basins of South America: AAPG Mem. 62, 165-183.

Gervais, A., Savoye, B., Mulder, T., \& Gonthier, E. (2006) Sandy modern turbidite lobes: a new insight from high-resolution seismic data. Mar. Petrol. Geol. 23, 485-502.

Gorsline, D.S. (1996) Depositional events in Santa Monica Basin, California Borderland, over the past five centuries. Sed. Geol., 104, 73-88.

Gorsline, D.S., De Diego, T. and Nava-Sanchez, E.H. (2000) Seismically triggered turbidites in small margin basins: Alfonso Basin, western Gulf of California and Santa Monica Basin, California borderland. Sed. Geol., 135, 21-35.

Haughton, P. D. (1994a) Deposits of deflected and ponded turbidity currents, Sorbas Basin, southeast Spain. J. Sed. Res., 64 (2).

Haughton, P. D., (2000b) Evolving turbidite systems on a deforming basin floor, Tabernas, SE Spain. Sedimentology, 47, 497518.

Hodgson, D. M., \& Haughton, P. D. (2004) Impact of syndepositional faulting on gravity current behaviour and deep-water stratigraphy: Tabernas-Sorbas Basin, SE Spain. Geol. Soc. London Spec. Publ., 222, 135-158.

Jegou, I., Savoye, B., Pirmez, C., \& Droz, L. (2008) Channel-mouth lobe complex of the recent Amazon Fan: The missing piece. Mar. Geol., 252, 62-77.

Johnson, S.D., Flint, S., Hinds, D. and De Ville Wickens, H. (2001) Anatomy, geometry and sequence stratigraphy of basin floor to slope turbidite systems, Tanqua Karoo, South Africa. Sedimentology, 48, 987-1023.

Jordan. T.E., Schlunegger, F. \& Cardozo, N. (2001) Unsteady and spatially variable evolution of the Neogene Andean Bermejo foreland basin, Argentina. J. S. Am. Earth Sci., 14, 775-798.

Kneller, B. (1995) Beyond the turbidite paradigm: physical models for deposition of turbidites and their implications for reservoir prediction. Geol. Soc. London Spec. Publ., 94, 31-49.

Kneller, B., Dykstra, M., Fairweather, L., \& Milana, J. P. (2016) Mass-transport and slope accommodation: implications for turbidite sandstone reservoirs. AAPG Bull., 100, 213-235.

Lamb, M.P., Toniolo, H. and Parker, G. (2006) Trapping of sustained turbidity currents by intraslope minibasins. Sedimentology, 53, 147-160.

Lien, T., Walker, R.G. and Martinsen, O.J. (2003) Turbidites in the Upper Carboniferous Ross Formation, western Ireland: reconstruction of a channel and spillover system. Sedimentology, 50,113-148.

Limarino, C. O., Césari, S. N., Net, L. I., Marenssi, S. A., Gutierrez, R. P., \& Tripaldi, A. (2002) The Upper Carboniferous postglacial transgression in the Paganzo and Rıo Blanco basins (northwestern Argentina): facies and stratigraphic significance. J. S. Am. Earth Sci., 15, 445-460.

López-Gamundí, O.R., Limarino, C.O., and Cesari, S.N. (1992) Late Palaeozoic palaeoclimatology of central west Argentina: Palaeogeogr. Palaeoclimatol. Palaeoecol., 91, 305-329. 
Lomas, S. A., \& Joseph, P. (2004) Confined turbidite systems. Geol. Soc. London Spec. Publ., 222, 1-7.

Malgesini, G., Talling, P. J., Hogg, A. J., Armitage, D., Goater, A., \& Felletti, F. (2015). Quantitative analysis of submarineflow deposit shape in the Marnoso-Arenacea Formation: what is the signature of hindered settling from dense near-bed

| layers?. J. Sed. Res., 85, 170-191.

Marini, M., Milli, S., Ravnås, R., \& Moscatelli, M. (2015) A comparative study of confined vs. semi-confined turbidite lobes from the Lower Messinian Laga Basin (Central Apennines, Italy): Implications for assessment of reservoir architecture. Mar. Petrol. Geol., 63, 142-165.

Marini, M., Felletti, F., Milli, S. and Patacci, M. (2016) The thick-bedded tail of turbidite thickness distribution as a proxy for flow confinement: Examples from tertiary basins of central and northern Apennines (Italy). Sed. Geol., 341, 96-118.

Milana, J. P., Kneller, B., \& Dykstra, M. (2010) Mass-transport deposits and turbidites, syn-to-post-glacial carboniferous basins of Western Argentina. ISC 2010F Guid, 01-88.

Mutti, E., \& Ricci Lucchi, F. (1978) Turbidites of the northern Apennines: introduction to facies analysis. Int. Geol. Rev., 20, 125-166.

Mutti, E. (1979) Turbidites et cones sous-marins profonds. Sédimentation détritique (fluviatile, littorale et marine), 1, 353-419.

Mutti, E., \& Normark, W. R. (1987) Comparing examples of modern and ancient turbidite systems: problems and concepts. In Marine clastic sedimentology (pp. 1-38). Springer Netherlands.

Mutti, E. (1992) Turbidite sandstones. Agip, Istituto di geologia, Università di Parma.

Normark, W. R. (1970) Growth patterns of deep-sea fans. AAPG Bull., 54, 2170-2195.

Normark, W. R. (1978) Fan valleys, channels, and depositional lobes on modern submarine fans: characters for recognition of sandy turbidite environments. AAPG Bull., 62, 912-931.

O'Connell, S., McHugh, C. and Ryan, W.B.F. (1995) Unique fan morphology in an entrenched thalweg channel on the Rhone Fan. In Atlas of Deep Water Environments (pp. 80-83). Springer Netherlands.

Palacios, Z. (2012) Climate Change as a Controlling Parameter in Sediment Supply: The Nile Province. PhD thesis, University of Aberdeen.

Picot, M., Droz, L., Marsset, T., Dennielou, B. and Bez, M. (2016) Controls on turbidite sedimentation: Insights from a quantitative approach of submarine channel and lobe architecture (Late Quaternary Congo Fan). Mar. Petrol. Geol., 72, 423446.

Pirmez, C., Beaubouef, R. T., Friedmann, S. J., \& Mohrig, D. C. (2000) Equilibrium profile and base level in submarine channels: examples from Late Pleistocene systems and implications for the architecture of deepwater reservoirs. In Global deep-water reservoirs: Gulf Coast Section SEPM Foundation 20th Annual Bob F. Perkins Research Conference (pp. 782-805).

Posamentier, H. W., \& Kolla, V. (2003) Seismic geomorphology and stratigraphy of depositional elements in deep-water settings. J. Sed. Res., 73, 367-388.

Prather, B. E., Booth, J. R., Steffens, G. S., \& Craig, P. A. (1998) Classification, lithologic calibration, and stratigraphic succession of seismic facies of intraslope basins, deep-water Gulf of Mexico. AAPG Bull., 82, 701-728.

Prather, B.E., Pirmez, C.A.R.L.O.S. and Winker, C.D. (2012) Stratigraphy of linked intraslope basins: Brazos-Trinity system western Gulf of Mexico. Application of the Principles of Seismic Geomorphology to Continental Slope and Base-of-Slope Systems: Case Studies from Seafloor and Near-Seafloor Analogues: SEPM Spec. Publ., 99, 83-110.

Prélat, A., Covault, J. A., Hodgson, D. M., Fildani, A., \& Flint, S. S. (2010) Intrinsic controls on the range of volumes, morphologies, and dimensions of submarine lobes. Sed. Geol., 232, 66-76.

Prélat, A., Hodgson, D. M., \& Flint, S. S. (2009) Evolution, architecture and hierarchy of distributary deepwater deposits: a highresolution outcrop investigation from the Permian Karoo Basin, South Africa. Sedimentology, 56, 2132-2154.

Pyles, D. R. (2007). Architectural elements in a ponded submarine fan, Carboniferous Ross Sandstone, western Ireland. Atlas of deep-water outcrops: AAPG Studies in Geology, 56, 206-209.

Ramos, V. A. (1989) Andean foothills structures in northern Magallanes Basin, Argentina. AAPG Bull., 73, 887-903.

Ravnås, R., \& Steel, R. J. (1997) Contrasting styles of Late Jurassic syn-rift turbidite sedimentation: a comparative study of the Magnus and Oseberg areas, northern North Sea. Mar. Petrol. Geol., 14, 417-449.

Remacha, E., \& Fernández, L. P. (2003) High-resolution correlation patterns in the turbidite systems of the Hecho Group (South-Central Pyrenees, Spain). Mar. Petrol. Geol., 20, 711-726.

Remacha, E., Fernández, L. P., \& Maestro, E. (2005) The transition between sheet-like lobe and basin-plain turbidites in the Hecho basin (south-central Pyrenees, Spain). J. Sed. Res., 75, 798-819.

Rozman, D.J. (2000) Characterization of a fine-grained outer submarine fan deposit, Tanqua-Karoo basin, South Africa. In: Fine-Grained Turbidite Systems (Eds A.H. Bouma and J. Stone), AAPG Mem., 72, 291-298.

Samuel, A., Kneller, B., Raslan, S,. Sharp, A. \& Parsons, C. (2003) Prolific Deep Marine Slope Channels of the Nile Delta, Egypt. AAPG Bull.. 87, 541-560

Sinclair, H. D. (1994) The influence of lateral basinal slopes on turbidite sedimentation in the Annot sandstones of SE France. J. Sed. Res., 64(1).

Smith, R. U. (2004) Silled sub-basins to connected tortuous corridors: sediment distribution systems on topographically complex sub-aqueous slopes. Geol. Soc. London Spec. Publ., 222, 23-43. 
Sumner, E. J., Talling, P. J., Amy, L. A., Wynn, R. B., Stevenson, C. J., \& Frenz, M. (2012) Facies architecture of individual basin-plain turbidites: Comparison with existing models and implications for flow processes. Sedimentology, 59, 1850-1887.

Talling, P. J., Amy, L. A., Wynn, R. B., Blackbourn, G., \& Gibson, O. (2007) Evolution of Turbidity Currents Deduced from Extensive Thin Turbidites: Marnoso Arenacea Formation (Miocene), Italian Apennines. J. Sed. Res., 77, 172-196.

Talling, P. J., Amy, L. A., \& Wynn, R. B. (2007). New insight into the evolution of large-volume turbidity currents: comparison of turbidite shape and previous modelling results. Sedimentology, 54, 737-769.

Thornburg, T. M., Kulm, L. D., \& Hussong, D. M. (1990) Submarine-fan development in the southern Chile Trench: a dynamic interplay of tectonics and sedimentation. Geol. Soc. Am. Bull., 102, 1658-1680.

Valdez Buso, V., Milana, J. P., \& Kneller, B. (2015) Megadeslizamientos gravitacionales de la Formación Guandacol en Cerro Bola y Sierra de Maz y su relación con la glaciación del Paleozoico Tardío, La Rioja, Argentina. Latin American journal of sedimentology and basin analysis, 22, 109-133.

Valdez Buso, V., di Pasquo, M., Milana, J.P., Kneller, B., Fallgatter, C., Chemale Junior, F. \& Paim, P. (2017) Integrated U-Pb zircon and palynological/palaeofloristic age determinations of a Bashkirian palaeofjord fill, Quebrada Grande (Western Argentina). J. S. Am. Earth Sci. 73. 202-222.

Van Rensbergen, P., Morley, C. K., Ang, D. W., Hoan, T. Q., \& Lam, N. T. (1999) Structural evolution of shale diapirs from reactive rise to mud volcanism: 3D seismic data from the Baram delta, offshore Brunei Darussalam. J. Geol. Soc. London, 156 , 633-650.

Vinnels J. S., Butler, R. W. H., Mccaffrey, W. D., Paton D. A. (2010) Depositional processes across the Sinu Accretionary Prism, offshore Colombia, Mar. Petrol. Geol., 27, 794-809.

Weaver, P. P. E., Rothwell, R. G., Ebbing, J., Gunn, D., \& Hunter, P. M. (1992) Correlation, frequency of emplacement and source directions of megaturbidites on the Madeira Abyssal Plain. Mar. Geol.,109, 1-20.

Wilson, T. J. (1983) Stratigraphic and structural evolution of the Ultima Esperanza foreland fold-thrust belt, Patagonian Andes, southern Chile. (Doctoral dissertation, Columbia University).

Wilson, T. J. (1991) Transition from back-arc to foreland basin development in the southernmost Andes: Stratigraphic record from the Ultima Esperanza District, Chile. Geol. Soc. Am. Bull., 103, 98-111.

Winker, C.D. (1996) High-resolution seismic stratigraphy of a Late Pleistocene submarine fan ponded by salt-withdrawal minibasins on the Gulf of Mexico continental slope: Pro-ceedings from 1996 Offshore Technology Conference, Paper OTC 8024, May 6-9, 1996, Houston, Texas, p. 619-628.

Wynn, R. B., Weaver, P. P., Masson, D. G., \& Stow, D. A. (2002) Turbidite depositional architecture across three interconnected deep-water basins on the north-west African margin. Sedimentology, 49, 669-695.

Wynn, R.B. Talling, P.J., Masson, D.G. Le Bas, T.P. Cronin, B.T. \& Stevenson, C. (2012) The Influence of Subtle Gradient Changes on Deep-Water Gravity Flows: A Case Study From the Moroccan Turbidite System. SEPM Spec. Publ. 99. 371-383.

Zapata T.R. \& Allmendinger R.W. (1996) Growth stratal records of instantaneous and progressive limb rotation in the Precordillera thrust belt and Bermejo basin, Argentina. Tectonics, 15, 1065-1 


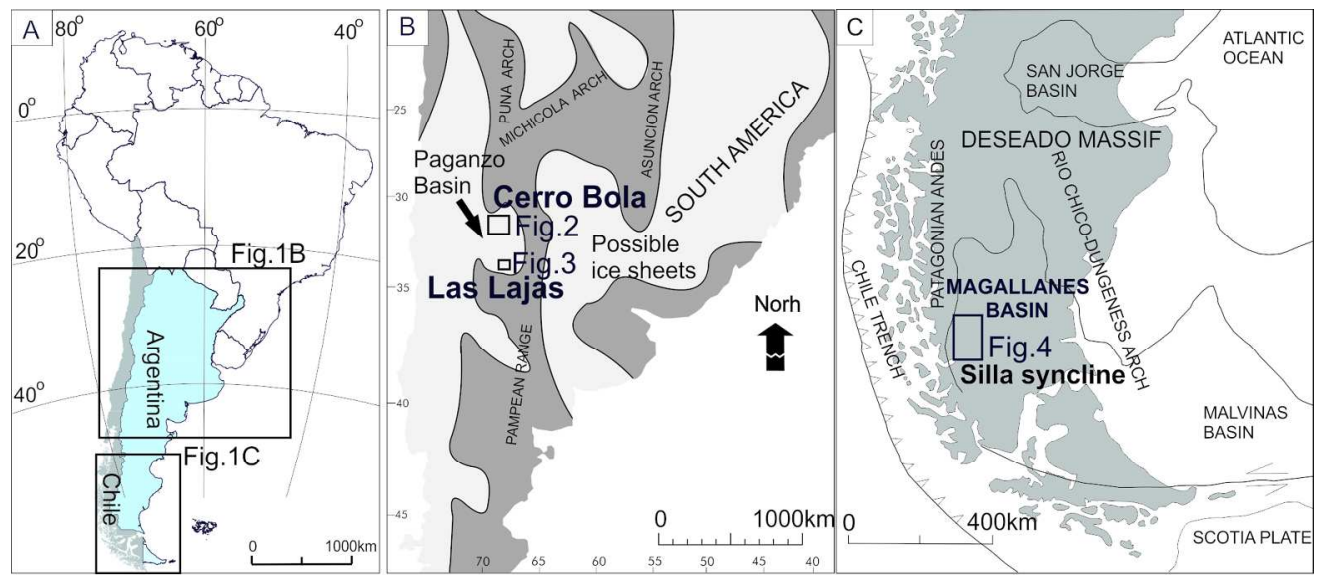

Fig.1 A. Geographic location of the field areas, maked as black squares. B. Palaeogeography of the Paganzo Basin (modified from Buatois and Mángano, 1995). The Paganzo basin was a restricted marine basin. The field localities, Cerro Bola and Las Lajas, are marked as black squares. C.Palaeogeographic map of Magallanes Basin (Crane and Lowe, 2008). The study area is marked as a black rectangle. 


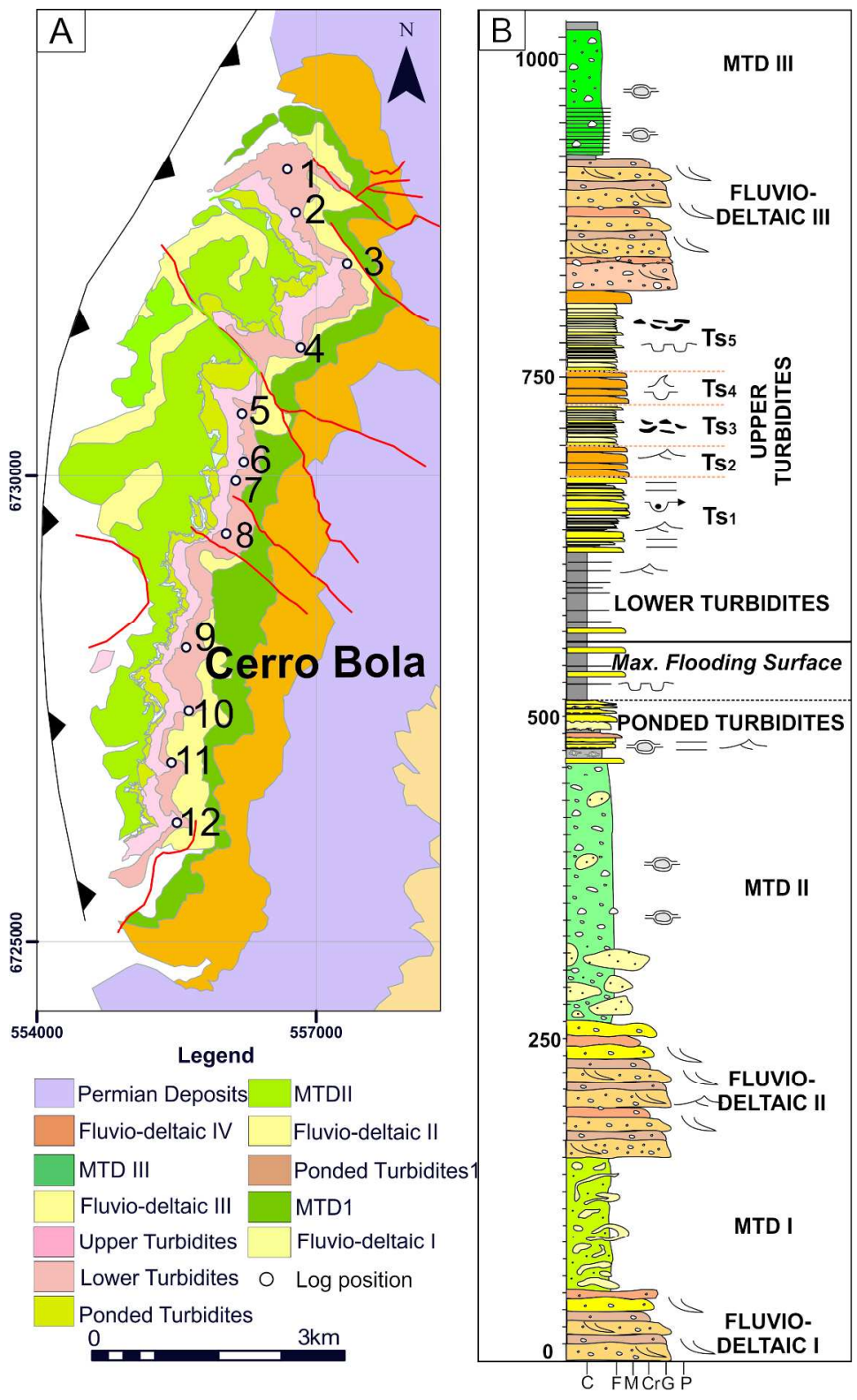

Fig.2. A. Geological map of Cerro Bola (after Valdez et al., 2015, modified from Dykstra et al., 2011). B.The stratigraphic column of Cerro Bola, represented by an alternation of fluvio-deltaic sediments, turbidite intervals and mass transport deposits (MTD). TS2 and TS4 in the upper turbidites interval are the subjects of this study. (Fallgatter et al., 2017, modified after Milana et al., 2010). 


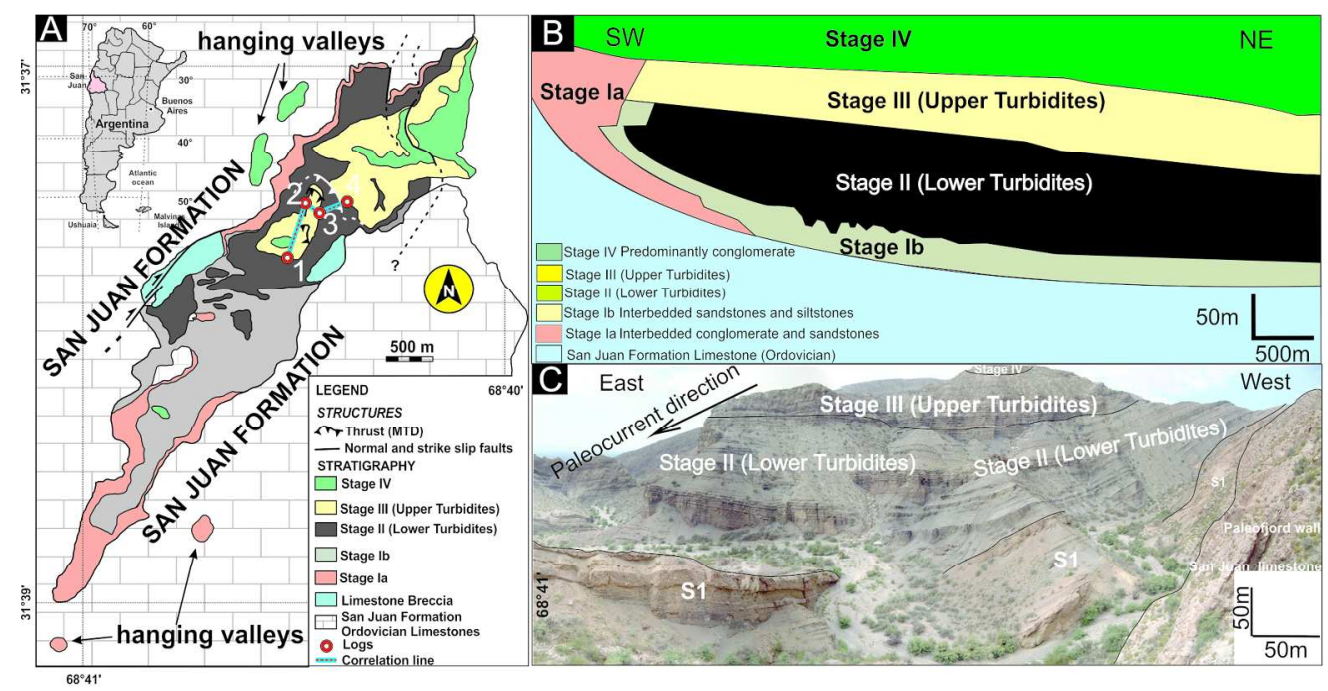

Fig.3. A. Geological map of Las Lajas (Fallgatter, 2015; modified after Dykstra et al., 2006) with sedimentary logs undertaken in this study are marked. B. Schematic longitudinal cross section of Las Lajas, showing the facies evolution of the palaeofjord (Dykstra et al., 2006). C. Panorama interpretation of the entire exposed succession in Las Lajas.

$180 \times 133 \mathrm{~mm}(300 \times 300 \mathrm{DPI})$ 


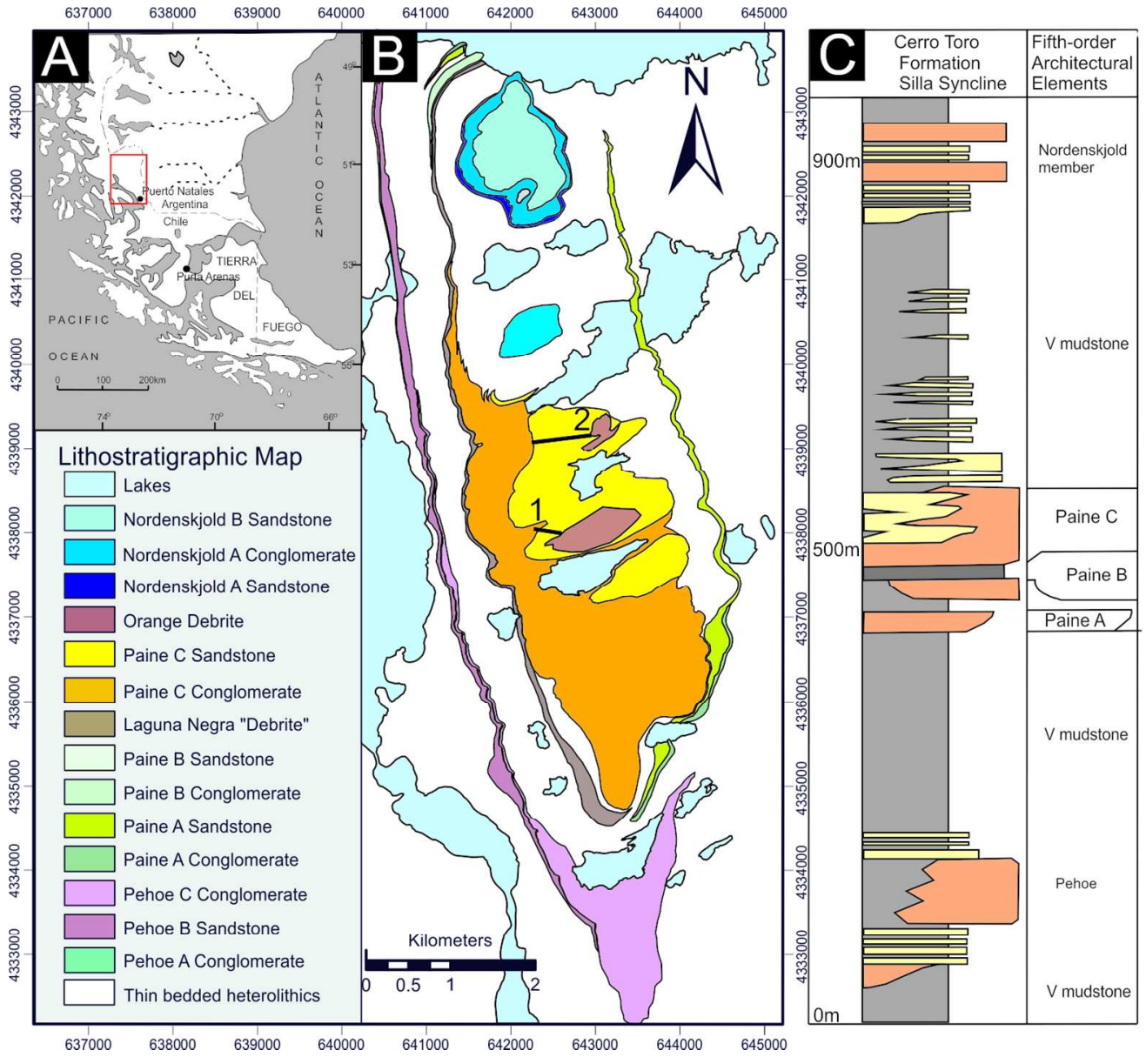

Fig. 4. A. General location map of the study area in southern Chile. B. Geological map of the Silla syncline showing the main units (modified from Crane \& Lowe 2008). Logged transects undertaken in this study are marked. C. Stratigraphic column of the Cerro Toro Formation in the Silla Syncline (modified from Crane and Lowe, 2008). 
Fig.5. A. Correlation panel of TS2 turbidite system. Positions of the logs shown on Fig.5B. Individual beds (Bed 1-Bed 21) have been correlated. B. Field position of the sedimentary logs. The dark grey arrow represent the palaeocurrent direction measured at each position. We can see that the correlation section is an oblique dip direction. C. Detailed sandstone properties of intervals logged, position showed in Fig.5A. The sand percentage is around $80 \%$. D. Position shown in Fig. 5A. The interval is dominated by thin-bedded turbidites, at the same horizon with Fig. 5C. 


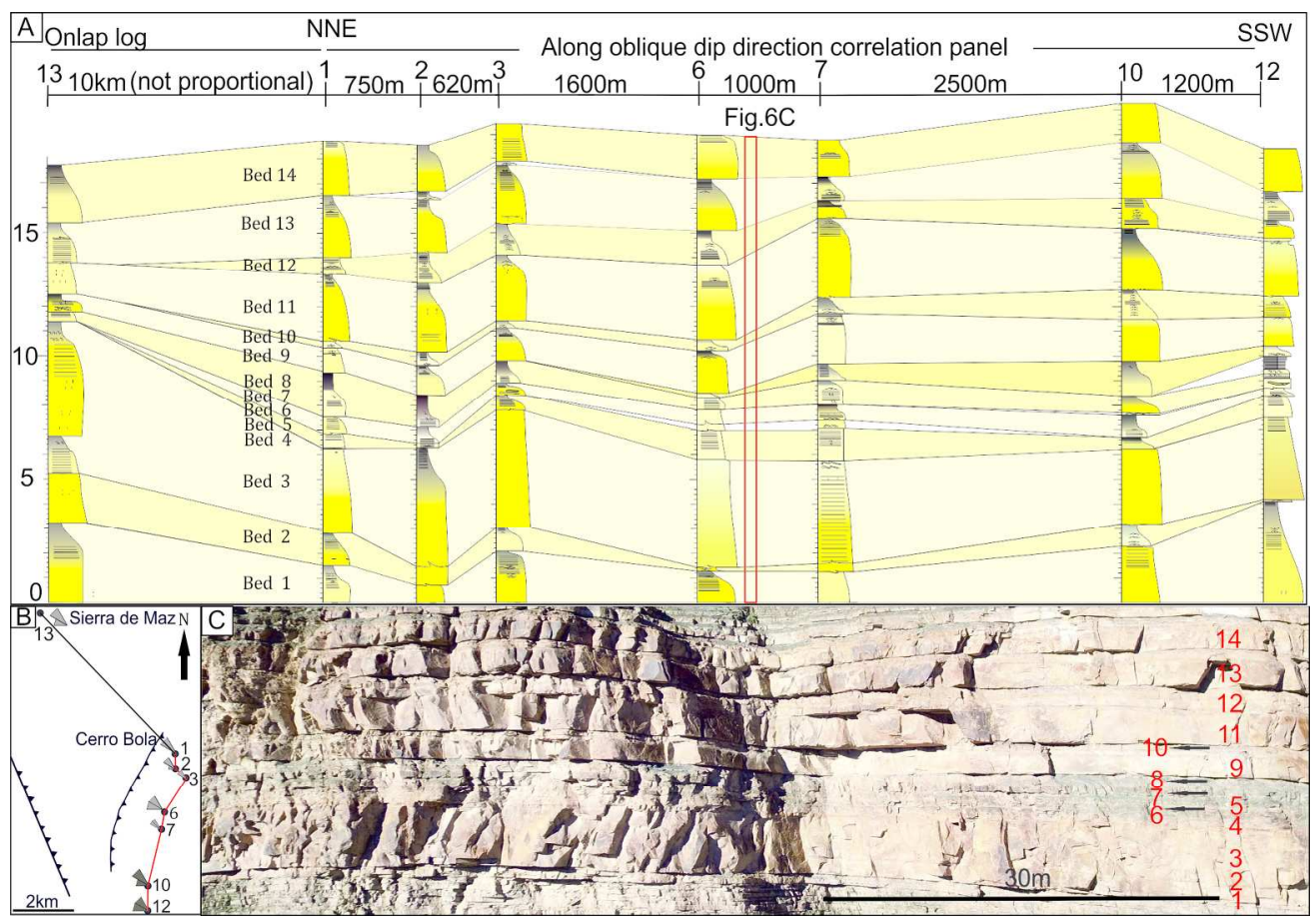

Fig. 6. A. Correlation panel of TS4 turbidite sheet sandstone, Cerro Bola. Positions of the logs shown on Fig.6B. Individual beds (Bed 1 - Bed 14) can be well correlated $7.6 \mathrm{~km}$ in oblique downdip and $12 \mathrm{~km}$ downdip to basin margin. B. Locations of logs in 6A, with palaeocurrent directions (marked with grey arrows). C. Individual beds could be clearly picked out in the field because of the silty mud cap. 


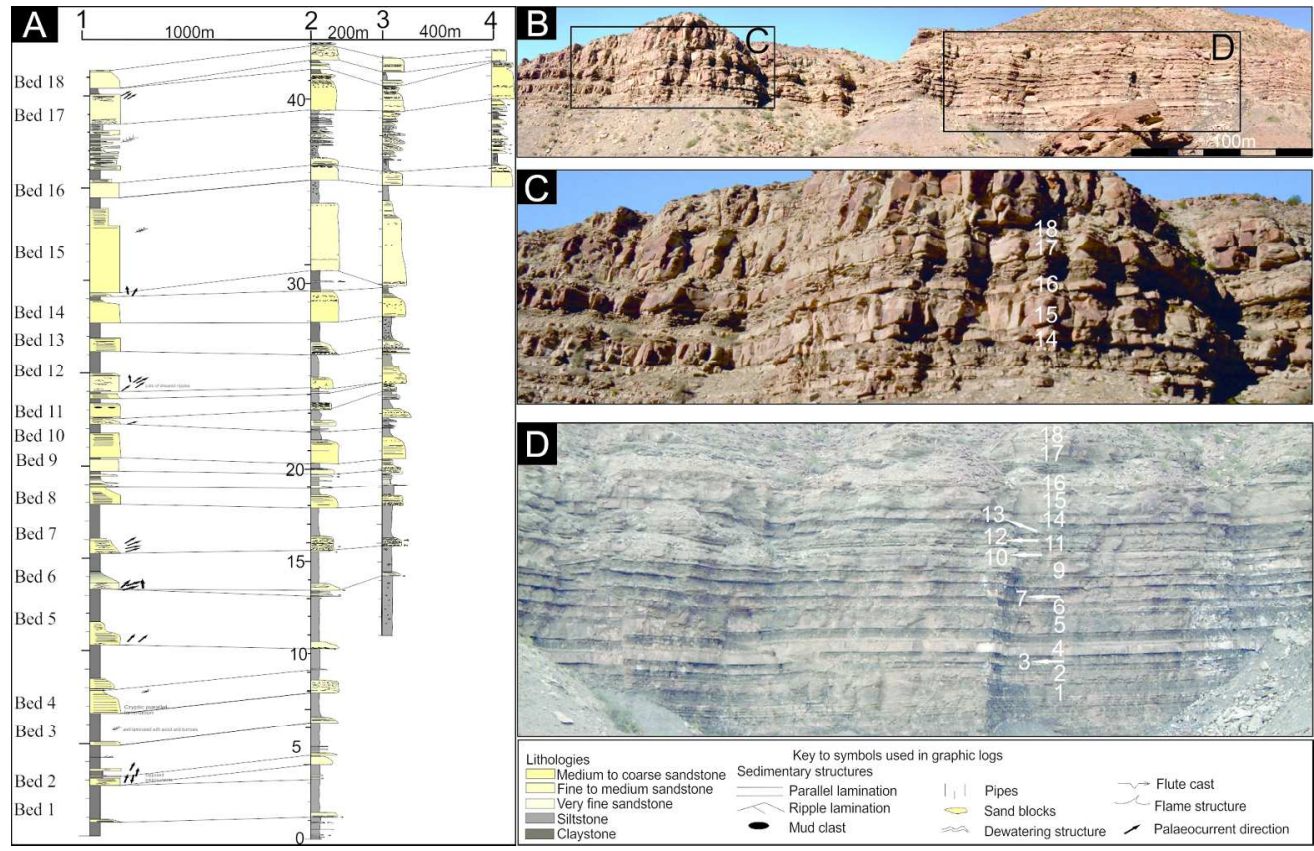

Fig.7. A. Correlation panel of Las Lajas turbidite sheet sandstones. Individual beds (Bed 1-Bed 18) could be well correlated. B. Panorama of the Las Lajas turbidite sheet sandstones. C. Close-up of the upper part of Las Lajas sandstone. Individual beds have mud caps. Beds (Beds 14-18) are labelled with numbers shown on the logs D. Close-up of the Las Lajas turbidite sandstone, position shown on Fig. 7B. Individual beds could be picked out easily on the outcrop image and in the field. Beds are labelled with numbers shown on the logs. 


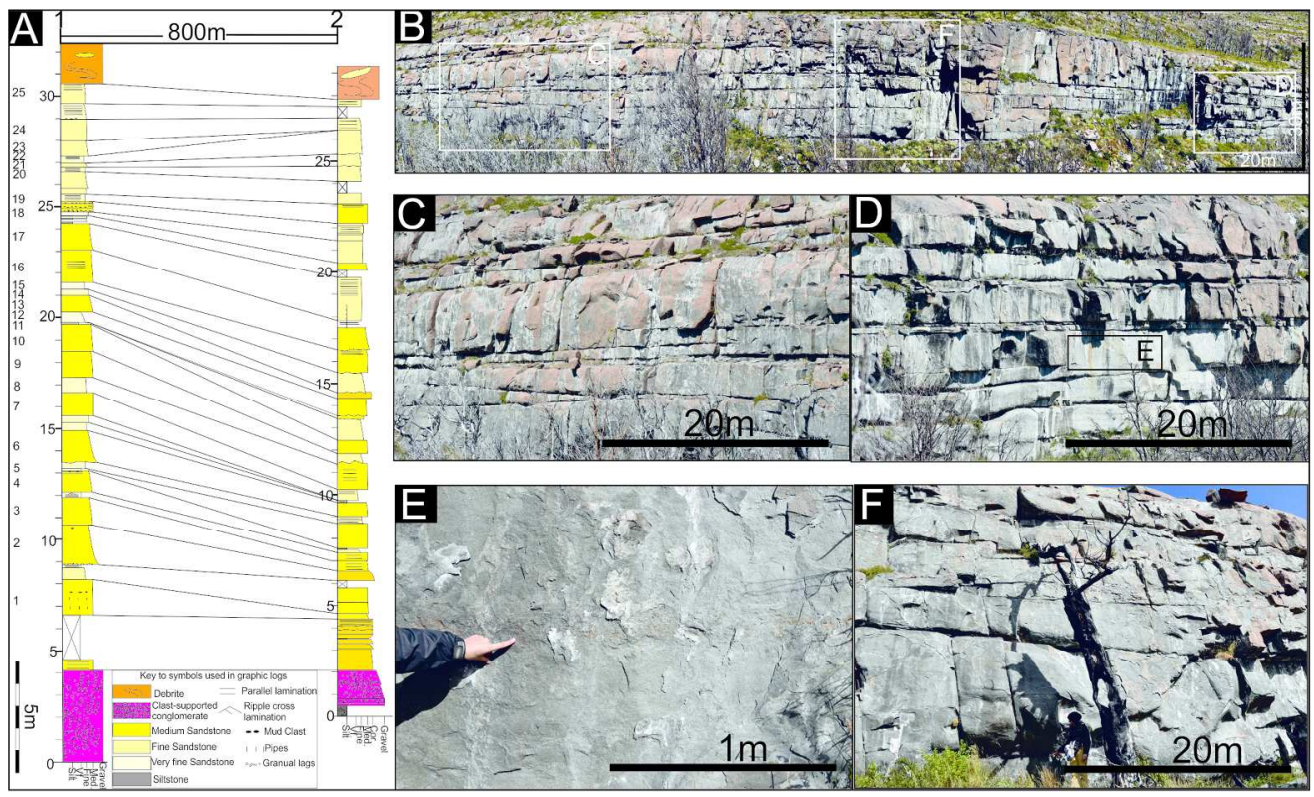

Fig. 8. A. Correlation panel of Paine C turbidite sandstone. Individual beds 1 to 25 have been correlated. B. Panorama view of the Paine $\mathrm{C}$ turbidite sandstone. C. Close-up of area labelled C on Fig. 8B. Bed pinch out and amalgamation can be seen. D. Close-up of area labelled D on Fig. 8B. $50 \mathrm{~cm}$ scour can be seen. E. Close-up of Fig.8D. Beds boundaries are represented by $10 \mathrm{~cm}$ granule-grade intervals (indicated on figure). F. Close-up of area labelled F on Fig. 8B.Packages (made up of several beds) change thickness over a distance of $20 \mathrm{~m}$, showing the non sheet-like nature of the Paine $C$ turbidites, even at a scale of tens of metres. 


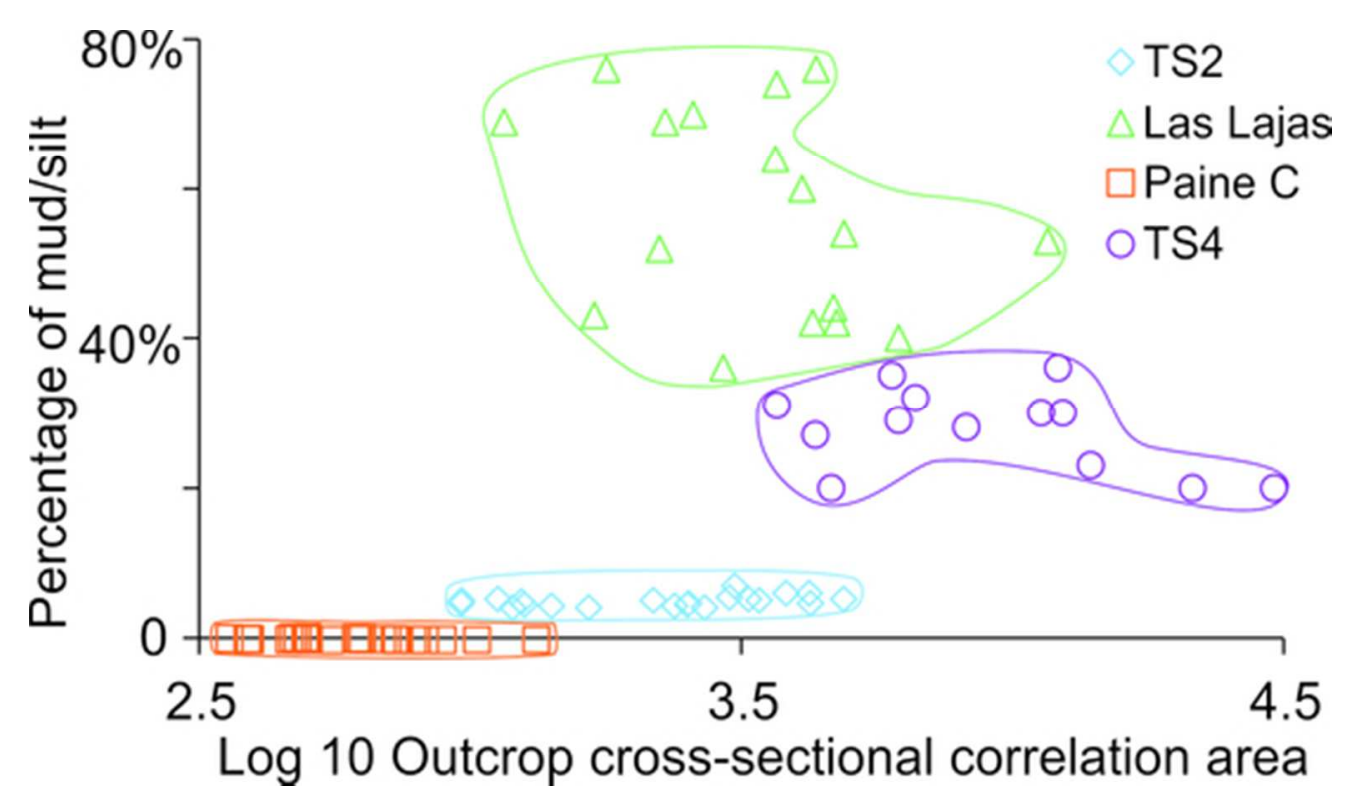

Fig. 9. Log10 outcrop cross sectional area against silt and mud percentage in the four systems. $46 \times 27 \mathrm{~mm}(300 \times 300$ DPI) 


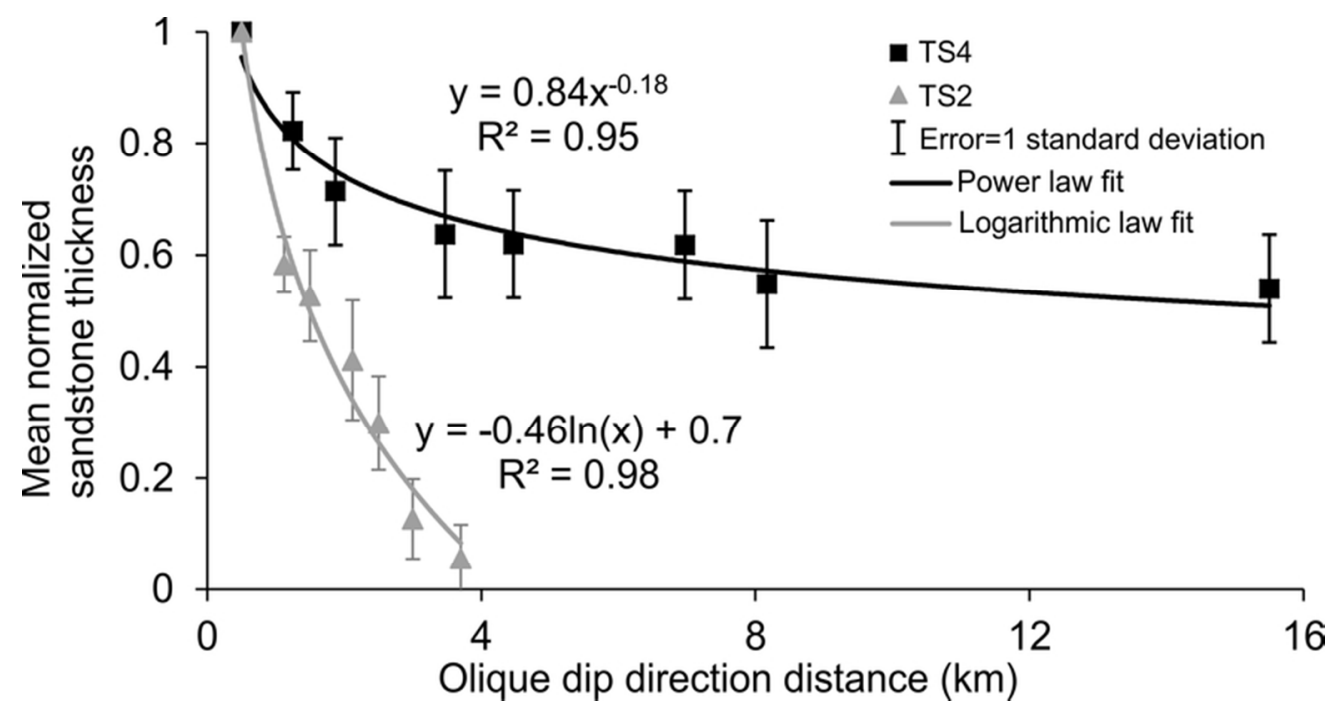

Fig. 10. Mean normalized thickness versus distance diagram for an oblique dip direction. Note that Individual beds in TS2 have an exponential decay in thickness, while individual beds in TS4 obey a power law decay.

$73 \times 38 \mathrm{~mm}(300 \times 300 \mathrm{DPI})$ 

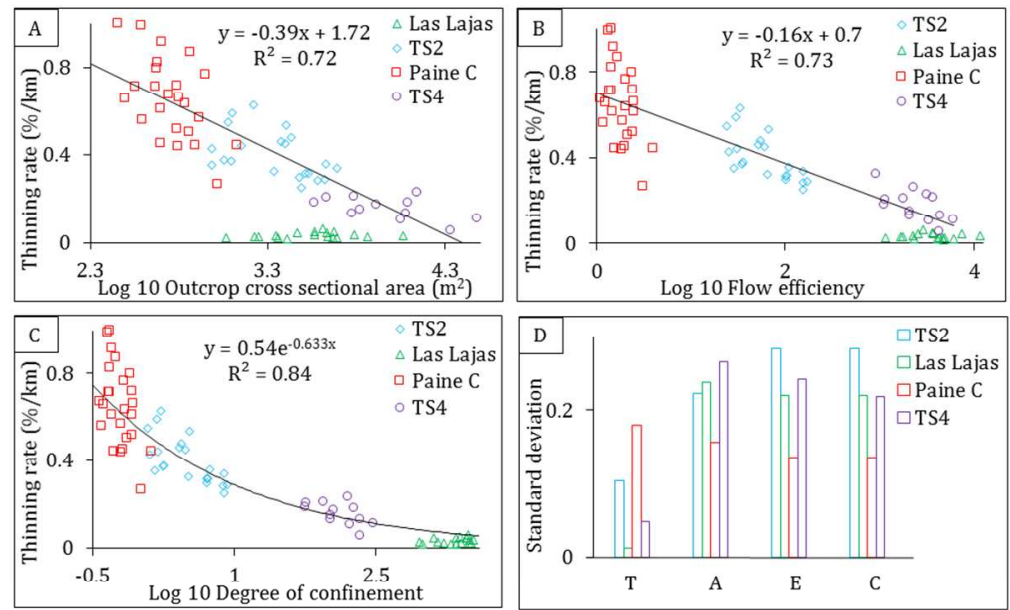

Fig. 11 A. Scatter plots of thinning rate $(\% / \mathrm{km})$ vs. Log 10 outcrop cross sectional area in four systems. B. Scatter plots of thinning rate $(\% / \mathrm{km})$ vs. Log 10 flow efficiency in four systems, thinning rate in Fig $10 \mathrm{~A}, \mathrm{~B}$ is exponential if plotted on a linear scale, C. Scatter plots of thinning rate $(\% / \mathrm{km})$ vs. Log 10 Degree of confinement in four systems, note power law best fit here, in contrast with linear fit in Fig. 10A, B. D. Histogram of standard deviation of T (thinning rates), A (Log10 outcrop cross sectional area), E (Log10 flow efficiency) and C (Log10 degree of confinement). 
Flow Efficiency
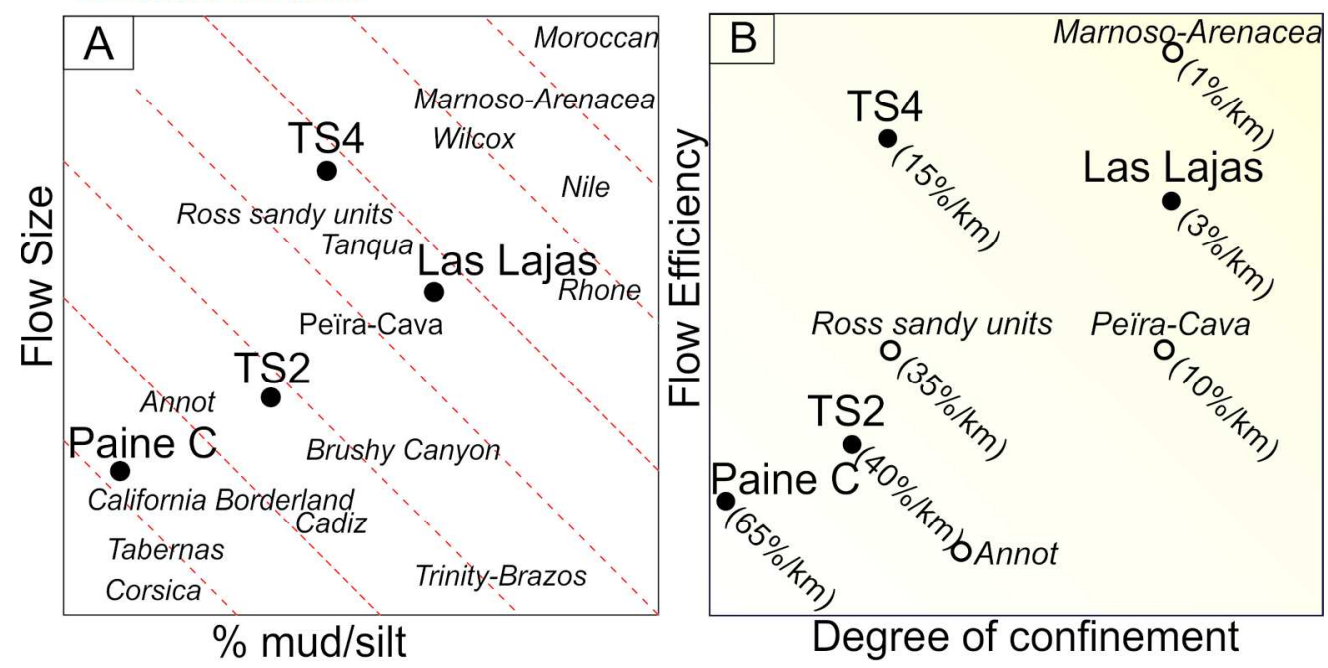

Fig. 12. A. Simplified diagram based on actual data in this study and approximate estimates of parameters of other turbidite systems based on published data. Red dashed lines represent equal values of flow efficiency. B. Schematic model built by combining the eight studied systems (four from this study and four from the published literature) based on flow efficiency, degree of confinement and average thinning rate. The colour gradient represent the decrease of thinning rate changing from low flow efficiency unconfined systems (left bottom corner) to high flow efficiency highly confined systems (right uppermost corner). 


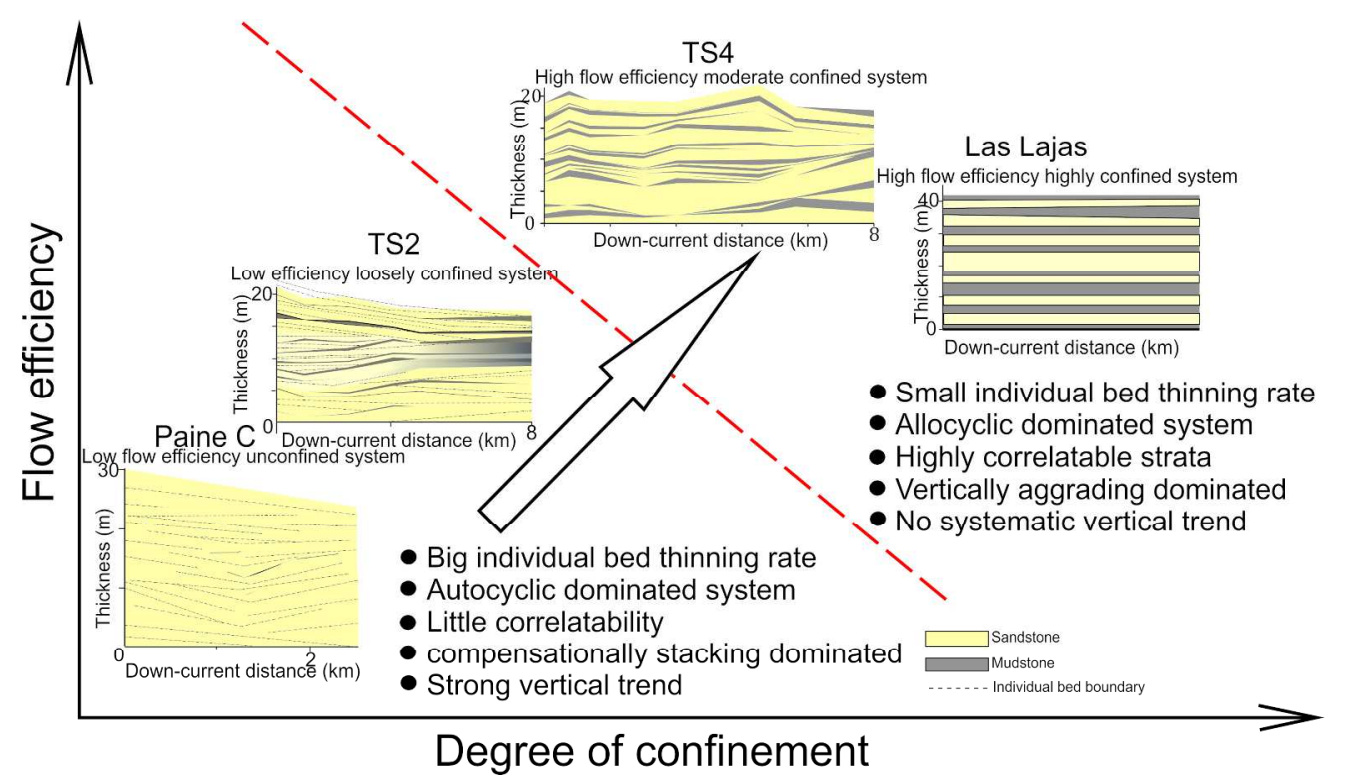

Fig. 13. Schematic cartoons showing the architecture of turbidite beds in the four systems. Paine $C$ turbidite sandstone represent the low flow efficiency loosely confined system in which individual bed pinch out quickly. TS2 turbidite sandstone represent the low efficiency moderately confined system in which individual beds could not be correlated for more than $2 \mathrm{~km}$. There is some compensational stacking at bed scale. Las Lajas represents the moderately efficient highly confined system, in which individual beds could potentially extend tens of kilometres with little change in bed thickness. TS4 represent the high flow efficiency highly confined system, in which individual beds could potentially extend tens of kilometres without much change in bed thickness. 
Table 1. Geological basin settings and outcrop characteristics of the four systems

\begin{tabular}{ccccc}
\hline & TS2 & TS4 & Las Lajas & Paine C \\
\hline Field area & Cerro Bola & Cerro bola & Las Lajas & Silla syncline \\
\hline Depositional setting & Subbasin & Subbasin & Palaeofjord & Confined slope \\
\hline Evidence of Confinement & $\begin{array}{c}\text { One margin seen at } \\
\text { outcrop, tectonic } \\
\text { restoration suggests } \\
\text { minimum basin width }\end{array}$ & $\begin{array}{c}\text { One margin seen at } \\
\text { outcrop, tectonic } \\
\text { restoration suggests } \\
\text { minimum basin width }\end{array}$ & $\begin{array}{c}\text { Palaeofjord walls } \\
\text { seen at outcrop }\end{array}$ & $\begin{array}{c}\text { Bounding surface } \\
\text { seen at outcrop }\end{array}$ \\
\hline Studied Interval thickness & $25 \mathrm{~m}$ & $25 \mathrm{~m}$ & $40 \mathrm{~m}$ & $40 \mathrm{~m}$ \\
\hline Orientation of outcrop & Oblique dip & Oblique dip & Oblique dip & Oblique dip \\
\hline Basin width & $20 \mathrm{~km}$ & $20 \mathrm{~km}$ & $0.8 \mathrm{~km}$ & $3 \mathrm{~km}$ \\
\hline Studied outcrop length & $7.6 \mathrm{~km}$ & $7.6 \mathrm{~km}$ & $2 \mathrm{~km}$ & $40 \%$ \\
\hline \%sand & $95 \%$ & $75 \%$ & $99 \%$
\end{tabular}


1

2

3

4

5

6

7

8

9

10

11

12

13

14

15

16

17

18

19

20

21

22

23

24

25

26

27

28

29

30

31

32

33

34

35

36

37

38

39

40

41

42

43

44

45

46

47

48

49

50

51

52

53

54

55

56

57

58

59

60

Table 2. Outcrop cross sectional area range, average outcrop cross section area, percentage of silt and mud in four systems

\begin{tabular}{ccccc}
\hline & TS2 & TS4 & Las Lajas & Paine C \\
\hline Outcrop cross sectional area $\left(\mathrm{m}^{2}\right)$ & 960 to 4890 & 3680 to 30380 & 1200 to 11600 & 290 to 1340 \\
\hline $\begin{array}{c}\text { Average outcrop cross-sectional } \\
\text { area }\left(\mathrm{m}^{2}\right)\end{array}$ & 2500 & 10900 & 4120 & 600 \\
\hline Percentage of silt and mud & $2 \%$ to $5 \%$ & $20 \%$ to $36 \%$ & $34 \%$ to $76 \%$ & $0.2 \%$ to $0.5 \%$
\end{tabular}


1

2

3

4

5

6

7

8

9

10

11

12

13

14

15

16

17

18

19

20

21

22

23

24

25

26

27

28

29

30

31

32

33

34

35

36

37

38

39

40

41

42

43

44

45

46

47

48

49

50

51

52

53

54

55

56

57

58

59

60

Table 3.Thinning rate $(\% / \mathrm{km})$, average flow efficiency, basin confinement and average degree of confinement in four studied systems: TS2, TS4, Las Lajas and Paine C.

\begin{tabular}{ccccc}
\hline & TS2 & TS4 & Las Lajas & Paine C \\
\hline Thinning rate $(\% / \mathrm{km})$ & $30-60$ & $5-23$ & $1-6$ & $45-100$ \\
\hline Average thinning rate $(\% / \mathrm{km})$ & 40 & 15 & 3 & 65 \\
\hline Average Flow efficiency & 76 & 2800 & 2160 & 1.8 \\
\hline Basin confinement $(\mathrm{km})$ & 20 & 20 & 0.8 & 3 \\
\hline Average Degree of confinement & 3.8 & 140 & 2700 & 0.6 \\
\hline
\end{tabular}


1

2

3

4

5

6

7

8

9

10

11

12

13

14

15

16

17

18

19

20

21

22

23

24

25

26

27

28

29

30

31

32

33

34

35

36

37

38

39

40

41

42

43

44

45

46

47

48

49

50

51

52

53

54

55

56

57

58

59

60

Table 4. Summary of the sedimentary characteristics of the four system.

\begin{tabular}{ccccc}
\hline Studied interval & Paine C & TS2 & Las Lajas & TS4 \\
\hline Represented systems & $\begin{array}{c}\text { Low efficiency } \\
\text { unconfined }\end{array}$ & $\begin{array}{c}\text { Low efficiency loosely } \\
\text { confined }\end{array}$ & $\begin{array}{c}\text { Highly efficient highly } \\
\text { confined }\end{array}$ & $\begin{array}{c}\text { Highly efficient } \\
\text { moderate confined }\end{array}$ \\
\hline $\begin{array}{c}\text { Individual bed thickness } \\
\text { change rate }\end{array}$ & high & high & Low & Low \\
\hline Cyclicity & Autocyclic dominated & Autocyclic dominated & Allocyclic dominated & Allocyclic dominated \\
\hline $\begin{array}{c}\text { Individual bed } \\
\text { Correlation confidence }\end{array}$ & low & low & high & high \\
\hline
\end{tabular}

